\title{
BELAJAR DARI KEARIFAN LOKAL UNTUK BERSIKAP TANGGAP BENCANA ALAM
}

\author{
Handajani Asriningpuri ${ }^{1}$, \\ ${ }^{1}$ Institut Teknologi Indonesia, Program Studi Arsitektur \\ hasriningpuri19@gmail.com
}

\begin{abstract}
:
Indonesia in archipelago arrangement completed by many tribes with all sorts of local wisdom and many catastrophe (natural disaster) that occurred or happened previously, included earthquake, which is one of catastrophe that happen previously. Respond to catastrophe can be done by anticipate to the past occurrence with consideration to and calculation about building construction system use the building code. The problem is nature as a place that weexist, occasionally not appreciate the fact and not completed the item that necessity but sometime the nature settled or arranged to full fill the human necessity, that is the problem make a catastrophe (natural disaster) happen. To solve that problem is to understand about nature attitude by applied the local wisdom continuously and if possible preserveit, as a demeanour respond to catastrophe. Descriptive qualitative comparative method will be used, by compared the traditional house in two locations. The outputs are to develop, expand and increase the science treasury in building materials and technology, the material renewable, structure and construction of comfort space theories, temperature-humidity-ventilation system-day lighting theories, related to ecological-greensustainability architecture approach, and to increase the building healthy and used age. The conclusion supposed will continued in the next research and will be inspiring the design resources
\end{abstract}

Key Words: catastrophe, local wisdom, traditional house.

\begin{abstract}
Abstrak :
Indonesia berada disusunan kepulauan dengan berbagai sukubangsa dengan berbagai kearifan lokal,dan berbagai bencana alam yang pernah atau akan terjadi, termasuk gempa bumi, salah satu dari bencana alam yang sering terjadi. Tanggap terhadap bencana alam dapat dilakukan antisipasi melalui pertimbangan terhadap perhitungan dan tatacara mendirikan bangunan yang disyaratkan oleh standart bangunan (building code). Permasalahan yang ada, alam sebagai tempat kita berada, kadang tidak dijadikan teman untuk dipahami dan diikuti berbagai hal yang diperlukan atau dituntut, tetapi kadang alam diatur dan dibuat mengikuti kebutuhan atau kepentingan manusia. Satu cara untuk kenal tentang alam adalah kenali penerapan kearifan lokal yang ada secara berkelanjutan. Karya ilmiah ini bertujuan untuk menyadarkan kita bahwa kearifan lokal harus dilestarikan secara berkelanjutan sebagai sikap tanggap terhadap terjadinya bencana alam.Metoda yang digunakan adalah diskriptif kualitatif komparative,dengan membandingkan keadaan bangunan rumah tradisional di dua lokasi. Luaran digunakan untuk pengembangan dan perluasan kasanah pengetahuan tentang material,teknologi penggunaan dan pemanfaatan material secara berkelanjutan (terbarukan),teori ruang\&kenyamanan , struktur-konstruksi,sistim penghawaan-suhukelembaban,pencahayaan, peningkatan kesehatan bangunan dan perpanjang usia pakai bangunandikaitkan pendekatan ekologi arsitektur,arsitektur hijau,arsitektur berkelanjutan. Diharapkan karya ilmiah dilanjutkan dengan penelitian lanjutan dan dimanfaatkan sebagai sumber inspirasi rancangan.
\end{abstract}

Kata Kunci : Bencana Alam, Kearifan Lokal, Rumah Tradisional

\section{PENDAHULUAN}

Tiga hal yang harus dipertimbangkan oleh disiplin arsitektur adalah pertama, lingkungan yang dimaksud adalah alam, dimana terdapat tanah dengan berbagai bentuk permukaan (topographi) maupun jenis dan kandungan didalam muka tanah (top soil), iklim dan musim, mata air dan sungai, tumbuhan dan hewan, perubahan ekologi akibat pertambahan usia alam dlsb, Alam sebagai tempat dimana bangunan berdiri melakukan perubahan ekologi yang bagi manusia dianggap sebagai bencana, kedua, bangunan misalnya rumah adalah produk manusia untuk memenuhi kebutuhan berlindung dari gangguan dan alam, kebutuhan dari nilai kepuasan atau martabat sebagai benda yang dibanggakan, kebutuhan sebagai bagian dari ragam budaya dan produk dari adat istiadat suatu daerah, ketiga manusia sebagai pengguna yang memerlukan alam untuk ditempati, keyakinan manusia tentang 
aturan dalam berkehidupan dengan alam, perilaku manusia yang berkaitan dengan adat istiadat harus dijaga, karenanya manusia sesungguhnya dapat mewarnai kebudayaan. Berkaitan dengan pendekatan arsitektur manusia dalam berperilaku kehidupan di alam dan sebagai perancang dan penata isi alam seyogyanya menjaga dan melestarikan warna budaya, terutama kearifan lokal. Oleh karenanya lingkungan, bangunan dan manusia harus dikaitkan satu sama lain secara erat dan dijadikan pertimbangan secara serentak (simultaneously).

Kadangkala alam diatur atau ditata sesuai atau mengikuti kepentingan dan kemauan manusia, karena bangunan dirancang untuk kebutuhan manusia, ditempatkan di alam, maka alamnya harus sesuai dengan bangunan, seharusnya bangunan yang ditempat kan di alam, maka bangunan yang diatur sesuai kondisi alam, karya ilmiah ini dilatarbelakangi oleh hal tersebut.

Indonesia memiliki berbagai suku bangsa, sudah tentu memiliki berbagai ragam kearifan lokal pula, terletak dikepulauan dengan berbagai bentuk topografi, jenis tanah,karakter pulau dan lautan, tentunya menghadapi berbagai bencana alam yang telah atau akan terjadi, termasuk gempa bumi, banjir, rob, tanah longsor, gunung erupsimeletus, kebakaran hutan, dan lain sebagainya, karena itu setiap insan bangsa Indonesia harus memiliki dan dapat bersikap tanggap bencana alam harus

\section{METODOLOGI}

Dimulai dengan penetapan sasaran (goals invention) sebagai hipotesa awal, bagian ini dilakukan pada tahap observasi melalui pengukuran dan rekam data lapangan termasuk melakukan survey kepustakaan yang terkait.Di tahap analisa.dari sasaran yang ditetapkan dengan mengkaitkan fakta dan kebutuhan teori terkait dirujuk pada konsep ideal (konsep yang paling mendekati permasalahan).Kemudian dari hasil analisa disusun dan dijabarkan permasalahan yang paling penting pada tahap sintesa.Dari hasil sintesa dirujuk pada pendekatan yang paling dekat relevansinya sebagai jawaban atau pemecahan masalah. Seluruh pemecahan masalah disimpulkan menjadi sebuah kesimpulan atau ditemukan hipotesa baru

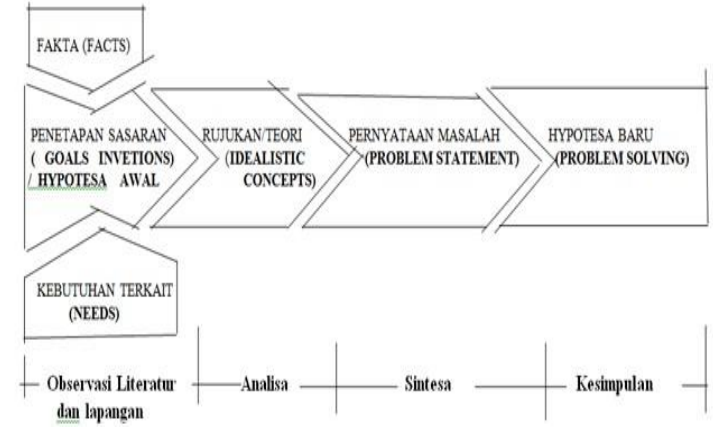

Diagram 1. Metodologi pembahasan Sumber : Dokumen Pribadi

\section{Permasalahan}

Permasalahannya di Indonesia selain tidak mengikuti standart,pelaku pembangunan tidak menerapkan sumberdaya manusia (sdm) yang sesuai kompetensinya, untuk menekan biaya menerapkan sdm yang memenuhi biaya sangpemilik bangunan.

Sikap tanggap bencana alam dapat dilakukan melalui antisipasi terhadap perhitungan dan pertimbangan tentang tatacara mendirikan bangunan sesuai yang disyaratkan oleh standart bangunan (building code). Selain itu dikenali, dipahami, dan diikuti secara tepat, benar dan berkelanjutan.penerapan kearifan lokal yang berlaku dan terdapat dilokasi.

\section{Kajian Pustaka.}

\section{Bencana Alam}

Menurut Nanda Yunisa, (2017) bencana alam adalah: Sesuatu yang memporakporandakan alam sekitar, menyebabkan kesusahan, kerugian, penderitaan, malapetaka disebabkan oleh alam seperti gempa bumi, angin besar, banjir, perubahan sifat dan keseimbangan alam atau sistim ecology diartikan sebagai bencana alam atau natural disaster (a "catastrophe").

\section{Gempa bumi dan Tsunami.}

Merujuk pada Ensiklopedia Jelajah Bumi (2017), gempa bumi adalah suatu gerakan mendadak merubah keadaan berguncang akibat pergeseran lapisan lempeng bumi yang saling bertubrukan, menimbulkan getaran pada permukaan bumi. Pergeseran tersebut timbul akibat dorongan material isi perut bumi yang berada dibagian dalam gunung berapi, baik yang aktif atau sudah tidak aktif, disebut gempa bumi vulkanik, pergeseran yang timbul akibat terjadinya patahan lempeng lapisan bumi bagian dalam disebut gempa tektonik. 
Sementara itu yang disebut Tsunami adalah: akibat getaran gempa tektonik atau erupsi gunung berapi menimbulkan riak dilaut yang besar semakin lama menjadi gelombang pasang besar menutupi permukaan lahan tepian pantai kemudian gelombang menjadi surut dari daratan kearah lautan berakibat menyeret permukaan tepian pantai kearah laut, menghancurkan permukaan bumi.

\section{Banjir}

Merujuk pada Ensiklopedia Jelajah Bumi (2017), Banjir adalah aliran air didalam sungai dalam volume atau jumlah besar dengan aliran deras berarus yang menerjang benda di depannya dan melimpah membawa material bongkahan batu atau tanah keseluruh permukaan tanah yang dilaluinya.Berkaitan dengan perubahan ekosistim alam terjadi banjir bandang yaitu banjir yangdatangnya tiba-tiba dalamjumlah besar dan berarus. Terdapat pula banjir rob yaitu banjir yang terjadi dikawasan tepian pantai akibat pasangsurut air laut.

\section{Iklim dan Musim}

Menurut Nanda Yunisa, (2017) bahwa iklim adalah suasana dan keadaan kuantitas dan kualitas tentang suhu / temperature udara, kelembaban udara, awan, hujan dan sinar matahari disuatu tempatdalam jangka waktu yang panjang/lama dan tertentu (periode), apabila jangka waktu (periode)nya lebih pendek (sedikit). Keadaan tersebut diatas, disebut cuaca. Iklim dan Musim adalah keadaan dari keterkaitan pergerakan bumi dan bulan pada poros mengelilingi mata-hari diruang angkasa. Sementara menurut Brenda Walpole, (2014) musim terjadi karena adanya perubahan kecondongan poros bumi kearah matahari selama bumi mengelilingi matahari (revolusi).

Jenis iklim ada dua: pertama iklim tropis yaitu iklim didaerah garis khatulis-tiwa (diantara $23^{\circ}$ Lintang Utara dan $23^{\circ}$ Lintang Utara, memiliki dua musim, yaitu musim kemarau dan musim penghujan, kedua iklim sub tropis diatas $23^{\circ}$ Lintang Utara atau Lintang Selatan kearah Kutub, memiliki empat musim: musim panas, musim gugur, musim dingin dan musim semi.

\section{Perubahan Iklim dan musim.}

Merujuk pada Brenda Walpole, (2014) bahwa iklim dan musim terjadi karena adanya pergerakan matahari bumi dan bulan pada porosnya diruang angkasa, bila ketiga penghuni ruang angkasa tersebut tidak pada tempatnya maka akan terjadi pergeseran dan perubahan iklim dan musim di bumi, yang berakibat pada perubahan ekosistim alam setempat, terkadang terjadi akibat ulah manusia merubah tatanan alam. Perubahan ekosistem yang besar menim-bulkan bencana, karena itu perubahan iklim dan musim sebaiknya diantisipasi dan diterima dengan sikap arif.

\section{Kearifan Lokal.}

Definisi Kearifan lokal menurut Ir.Siswono Yudohusodo dkk (1990) adalah dasar dari sebuah tradisi yang merupakan adat istiadat menjadi kebudayaan dari masyarakat suku setempat, atau bangsa; unsur dasarnya tumbuh, berkembang dan bertahan lama, melekat pada diri masyarakat yang bersangkutan, secara turun menurun, memberikan warna dan karakter yang unik-spesifik.;

Menurut pernyataan Lembaga Bangunan Hijau konsulat Indonesia/GBCI (Green Building Council Indonesia).pada bahwa aspek pertimbangan bangunan hijau termasuk bagian dari kerifan lokal.

\section{Rumah Tradisional}

Menurut Bernard Rudofsky (1964) bahwa arsitektur tradisional adalah sama dengan arsitektur vernakular, bangunan tradirional merupakan bentuk arsitektur yang diproduksi oleh masyarakat setempat dengan aturan atau ketentuan yang sesuai dengan keyakinan yang dianut masyarakat sesuai dengan keadaan alam atau lingkungan setempat, sesuai dengan gaya hidup dan kemahaman religi setempat, diterapkan teknologi sederhana yang disesuaikan dengan pengetahuan bahan dan pertimbangan pada keseimbangan alam, disebut produk arsitektur vernakular karena sangat sesuai dengan karakter lingungan.

$$
\text { Sementara menurut: Ir.Siswono }
$$
Yudohusodo dkk (1990) bahwa Rumah tradisional adalah ungkapan bentuk karya manusia yang merupakan unsur kebudayaan setempat yang tumbuh dan berkembang di masyarakat, suku, atau bangsa; unsur dasarnya bertahan lama, melekat pada diri masyarakat yang bersangkutan.

Menurut Barry Dawson dkk, (1994) bahwa arsitektur tradisional adalah suatu produk dari lingkungan berbeda dimana keanekaragamannya didapat dari tatacara yang sama tanpa ada perubahan, membudaya dari generasi ke generasi dan penggunaan bahan atau materialnya melalui tanggapan terhadap kondisi iklim dan vegetasi setempat.

Menurut OLIVER J RAPP (2015), rumah tradisional adalah rumah yang bentuk dan cara 
pembuatannya diwariskan secara turun temurun. dihuni satu keluarga, dengan struktur utama kayu atau bambu utuh, penutup atap menggunakan alang $^{2}$, rumbia, daun kelapa, ijuk, bambu belah sirap, seng, atau genting.

\section{Orientasi Bangunan.}

Merujuk pada buku KAMPUNG NAGA Permukiman Warisan Karuhun (Dinas Pariwisata dan Kebudayaan provinsi Jawa Barat Pemerintah Kabupaten Tasimalaya (2001); bahwa secara keseluruhan orientasi atap bangunan rumah tradisional sunda di kampung naga terlihat membujur arah Timur-Barat, bangunannya saling ber- hadapan kearah Utara-Selatan.

Sementara jika merujukan pada Josef Priyotomo dkk (2017), bahwa rumah Jawa termasuk bangunan Nusantara, umumnya memanjang dari Timur ke Barat menghadap ke Utara atau sebaliknya (Utara-Selatan), bangunan berbentuk persegi empat dengan arah bubungan atap berlawanan dengan datangnya hembusan angina yang arah datangnya angin dari arah BaratUtara (Barat Laut) atau dari arah Timur-Selatan (Tenggara).

Menurut Andrian Tecky dkk (2014) bahwa penyusunan dan pengarahan masa bangunan yang tepat akan bedampak pada pola gerakan dan kecepatan aliran udara. Sementara menurut Livingstone,2014 dalam Parmonangan Manurung (2017) bahwa Cahaya yang masuk dari sisi Utara atau Selatan bangunan merupakan cahaya tidak langsung yang dapat dimasukan dalam jumlah besar kedalam bangunan melalui bukaan yang besar akan tetapi didapatkan kalor yang kecil.

Merujuk pada Dwita Hadi Rahmi (2015) bahwa bangunan akan menguntungkan bila tidak langsung terpapar sinar matahari dengan cara diletakkan menghadap Selatan-Utara, membujur pada arah Timur-Barat.

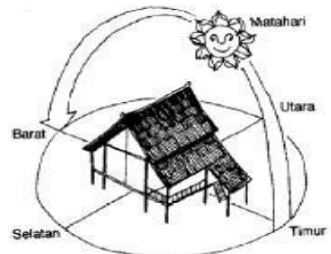

Gambar 2.Orientasi bangunan terkait matahari Sumber : Dwita Hadi Rahmi (2015)

Menurut Triharso K(2016) bahwa Bangunan sebaiknya menghadap Utara-Selatan agar penerimaan panas akibat cahaya matahari pada bangunan menjadi sedikit, manfaat lain dari penempatan orientasi bangunan adalah untuk mendapatkan aliran udara kedalam ruangan dapat dikontrol sesuai kebutuhan dan besaran ruang.

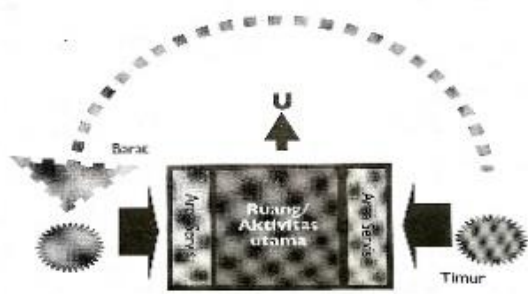

Gambar 3.Orientasi bangunan terkait matahari Sumber : Triharso Karyono (2016)

\section{PEMBAHASAN}

Lokasi

Rumah tradisional Sunda, diwakili perumahan Kampung Naga di Desa Neglasari, Kecamatan Salawu, Kabupaten Tasikmalaya, Jawa Barat sebagai konsep ideal, Rumah tradisional Jawa diwakili perumahan di Kampung Bade, Desa Klego, Kecamatan Karanggede, Kabupaten Boyolali Jawa Tengah.

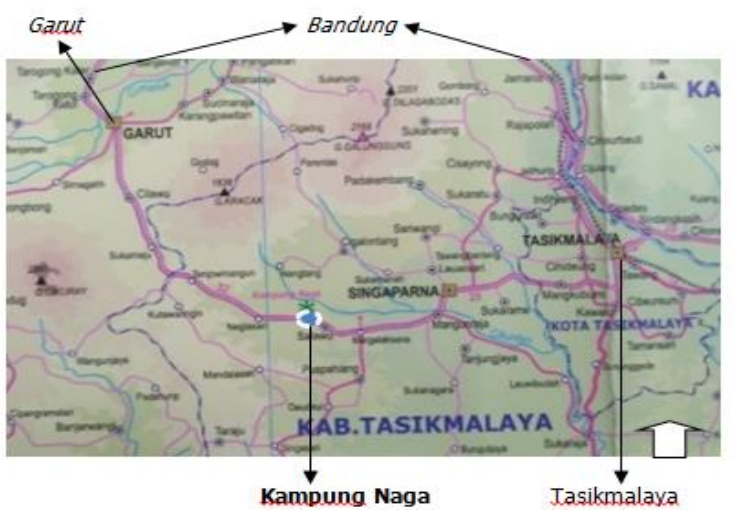

Gambar 4. Jawa Barat

Sumber : Peta Pariwisata CV INDO BUWANA

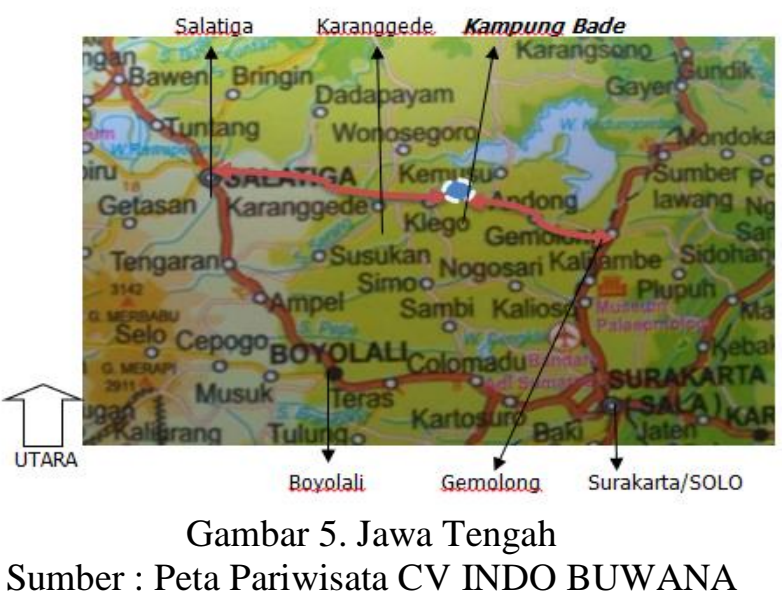

Sumber : Peta Pariwisata CV INDO BUWANA 
Tabel.1. Kharakter Kampung

\begin{tabular}{|c|c|c|c|}
\hline & Tempat & Pencapaian & Karakter \\
\hline Kampung Naga & $\begin{array}{l}\text { Nama aslinya kampung } \\
\text { Nagawir di desa Neglasari } \\
\text { Salawu Garut }\end{array}$ & $\begin{array}{l}\text { Mudah dicapai karena } \\
\text { terletak dijalan raya Garut } \\
\text { - Tasikmalaya }\end{array}$ & $\begin{array}{l}\text { Budaya lokal sangat kuat } \\
\text { sehingaga tidak terpengaruh } \\
\text { o/adanya kemajuan tekno- } \\
\text { logi walau mudah dicapai } \\
\text { dari luar,disebut sebagai } \\
\text { kearifan lokal }\end{array}$ \\
\hline Kampong Bade & $\begin{array}{l}\text { Awalnya dinamakan } \\
\text { kampung wates, karena } \\
\text { ada dua nama wates, maka } \\
\text { kemudian dirubah menjadi } \\
\text { "Bade" yg artinya hendak, } \\
\text { harapan penduduknya } \\
\text { memiliki banyak kehendak } \\
\text { /keinginan, sebagai sebuah } \\
\text { kreatifitas }\end{array}$ & $\begin{array}{l}\text { Sangat mudah dicapai } \\
\text { karena terletak dijalan } \\
\text { raya propinsi Karang gede } \\
\text { Gemolong }\end{array}$ & $\begin{array}{l}\text { Dimulai th } 1995 \text { di era } \\
\text { reformasi penduduk banyak } \\
\text { yang pergi ke kota besar } \\
\text { demi pengembangan diri, } \\
\text { pengetanuan, kemahiran } \\
\text { dan upah, ketika kembali } \\
\text { seluruh aspek pengembang } \\
\text { an merubah gaya hidup } \\
\text { termasuk bentuk rumah }\end{array}$ \\
\hline
\end{tabular}

Sumber: Dokumen pribadi

\section{Kondisi Tapak dan Ekosistim.}

Kondisi tapak kampung Naga berada disekelilingi antara bukit Singaparna dan Bukit Karan, kurang lebih $800 \mathrm{~m}$ turun dari jalan raya propinsi ke lokasi permikiman, berada di ketinggian $\pm 654 \mathrm{~m}$ dari permukaan laut,dengan kemiringan lahan cukup curam $\pm 60^{\circ}$, akan tetapi pada lahan permukiman cukup datar $\pm 10^{\circ}$ kemiringn muka tanah dari bukit kearah sungai, mengikuti sebagian aliran sungai, yang digunakan sebagai sarana drainase. Sumber air bersih diambil dari mata air yang terdapat di kedua bukit, diantara perumahan dan sungai terdapat sarana drainase, persawahan dan kolamikan sebagai sumber matapencaharian.Hunian, makam orangtua dan leluhur serta sumber kehidupan berada dalam kesatuan yang tertata dan teratur. Bangunan membujur Timur-Barat; hadapan rumah UtaraSelatan; orientasibangunan kearah masjid dan lapangan kecil sebagai pusat kegiatan : untuk menjemur hasil panen, bermusya-warah, berolah raga dan bermain.

Tapak Kampung Bade terletak dikecamatan Klego dijalan raya propinsi antara kecamatan Karanggede-Gemolong $\pm 27 \mathrm{~km}$ dari Gemolong. Kampung Bade terletak didataran rendah dengan topographi berbukitdiawalan pegunungan "Kendengs"di $\pm 540 \mathrm{~m}$ permukaan laut, lahannya terbagi dua dipisahkan oleh jalan raya dimana topographi menurun ke sisi Utara sampai dengan "Kali Serang" di level topographi terendah, dari jalan raya kearah Selatanmenurun sampai dengan Waduk Bade dan sungai Pepeyang berasal dari Susukan,Boyolali, waduk "Cengklik" dikaki bukit sisi Barat Daya.
Tabel 2: Tapak dan Ekosistem

\begin{tabular}{|c|c|c|}
\hline $\begin{array}{l}\text { Aspek } \\
\text { Tinjauan }\end{array}$ & $\begin{array}{c}\text { Kampung } \\
\text { Naga }\end{array}$ & $\begin{array}{c}\text { Kampung } \\
\text { Bade }\end{array}$ \\
\hline $\begin{array}{l}\text { Orientasi } \\
\text { rumah }\end{array}$ & Utara-Selatan & Utara-Selatan \\
\hline $\begin{array}{l}\text { Bentuk } \\
\text { rumah }\end{array}$ & $\begin{array}{l}\text { Bujur sangkar / } \\
\text { persegi empat }\end{array}$ & persegi empat \\
\hline $\begin{array}{l}\text { Dimensi } \\
\text { rumah }\end{array}$ & $\begin{array}{l}\text { Min } 36 \mathrm{~m}^{2} \\
\text { maks } 66 \mathrm{~m}^{2}\end{array}$ & $\begin{array}{l}\text { Min } 54 \\
\mathrm{~m}^{2} ; \max 135 \mathrm{~m}^{2}\end{array}$ \\
\hline $\begin{array}{l}\text { Topographi } \\
\text { kemiringan } \\
\text { lahan }\end{array}$ & $8^{\circ} \mathrm{s} / \mathrm{d} \pm 45^{\circ}$ & $8^{\circ} \mathrm{s} / \mathrm{d} \pm 15^{\circ}$ \\
\hline Iklim & Tropis Lembab & Tropis lembab \\
\hline Musim & $\begin{array}{l}\text { Kemarau dan } \\
\text { Penghujan }\end{array}$ & $\begin{array}{l}\text { Kemarau } \\
\text { \&Penghujan }\end{array}$ \\
\hline Letak & $7^{\circ} 56^{\prime} 49^{\prime \prime}-7^{\circ}$ & $7^{\circ} 50^{\prime} 27^{\prime \prime}-7^{\circ}$ \\
\hline Geographis & $\begin{array}{l}56^{\prime} 49^{\prime \prime} \text { LS } \\
107^{\circ} 25^{\prime} 8^{\prime \prime} \\
\text { Bujur Timur }\end{array}$ & $\begin{array}{l}56^{\prime} 49^{\prime \prime} \mathrm{LS} \\
108^{\circ} 18^{\prime} 32^{\prime \prime} \mathrm{Buj} \\
\text { urTimur }\end{array}$ \\
\hline $\begin{array}{l}\text { Temperatur } \\
\text { rata-rata }\end{array}$ & $\begin{array}{l}21,5^{\circ} \mathrm{C}-24,1^{\circ} \mathrm{C} \\
\text { (kemarau) pd25- } \\
\text { 29Juni } 2018\end{array}$ & $\begin{array}{l}30,5^{\circ} \mathrm{C}- \\
32,8^{\circ} \mathrm{Ckemara} \\
\text { upd } 25 \text { April- } \\
\text { 3Mei } 2018\end{array}$ \\
\hline Kelembaban & $70 \%-80 \%$ & $40 \%-60 \%$ \\
\hline $\begin{array}{l}\text { Suhu ruang: } \\
\text { pagi }\end{array}$ & $\begin{array}{l}18,3^{\circ} \mathrm{C}-20,1^{\circ} \mathrm{C} \\
21,5^{\circ} \mathrm{C}-24,1^{\circ} \mathrm{C}\end{array}$ & $\begin{array}{c}20,5^{\circ} \mathrm{C}- \\
21,8^{\circ} \mathrm{C}\end{array}$ \\
\hline $\begin{array}{r}\text { Siang } \\
\text { malam }\end{array}$ & $16,5^{\circ} \mathrm{C}-18,1^{\circ} \mathrm{C}$ & $\begin{array}{c}30,5^{\circ} \mathrm{C}- \\
32,8^{\circ} \mathrm{C} \\
16,3^{\circ} \mathrm{C}- \\
20,1^{\circ} \mathrm{C}\end{array}$ \\
\hline $\begin{array}{l}\text { Elemen } \\
\text { disekitar }\end{array}$ & $\begin{array}{l}\text { S“Ciwulan" } \\
\text { disisi Timur , } \\
\text { dua bukit disisi } \\
\text { Utara }\end{array}$ & $\begin{array}{l}\text { "Kali Serang" } \\
\text { disisi Utara. } \\
\text { "Waduk Bade" } \\
\text { disisi Selatan }\end{array}$ \\
\hline $\begin{array}{l}\text { Sinar } \\
\text { matahari }\end{array}$ & $\begin{array}{l}\text { Cerah, Kuat } \\
\text { terang cahaya } \\
\text { tinggi }\end{array}$ & $\begin{array}{l}\text { Cerah Kuat } \\
\text { terang cahaya } \\
\text { sangat tinggi }\end{array}$ \\
\hline Cahaya & Cerah dan & Terang dan \\
\hline Matahari & $\begin{array}{l}\text { terang kadang } \\
\text { kala redup }\end{array}$ & $\begin{array}{l}\text { kadang kala } \\
\text { silau. }\end{array}$ \\
\hline Aliran udara & $\begin{array}{l}\text { Sejuk, angin } \\
\text { bertiup } \\
\text { sepoi }^{2} \text { Kadang }^{2} \\
\text { tidak ada angin, } \\
\text { Dingin di } \\
\text { malam hari }\end{array}$ & $\begin{array}{l}\text { Panas,kadang } \\
\text { kala hangat \& } \\
\text { dingin pada } \\
\text { pagi hari }\end{array}$ \\
\hline
\end{tabular}

\section{Objek Kajian \\ Rumah Sunda.}

Berbentuk rumah panggung, pada umumnya mendapatkan aliran udara kedalam bangunan secara optimal, karena terdapat jarak antara lantai (dibuat dari jalinan bambu disebut 
palupuh) dengan permukaan tanah dibawahnya berjarak setinggi batu umpak (pondasi) $\pm 60 \mathrm{~cm}$, umpak digunakan sebagai tumpuan tiang utama bangunan. Bahan utama bangunan terbuat dari Kayu "Manglid" dan bambu. Bentuk atap pelana disebut bentuk "Suhunan Jolopong " ditutup dengan daun aren dilapisi daun "Tepus" dibawahnya, hal ini mendinginkan suhu didalam ruangan. Penghuni rumah selalu melakukan ritual secara taat dan terus menerus (berkelanjutan) terutama ketika

akan berdagang, panen hasil bumi, hasil perikanan, hasil peternakan mempersiap kan perbaikan rumah, mencari bahan bangunan dihutan, dengan sangat antu-sias mempersiapkan makanan bagi leluhur, karena dianggap sebagai rasa syukur pada Tuhan YME dan alam sekitar, oleh karenanya bangunan sunda di Kampung Naga tidak tergusur oleh perubahan kemajuan teknologi, dise-babkan oleh kesetiaannya terhadap adat.

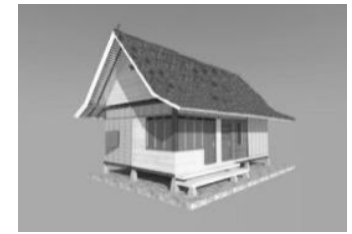

$6 . a$

6.c

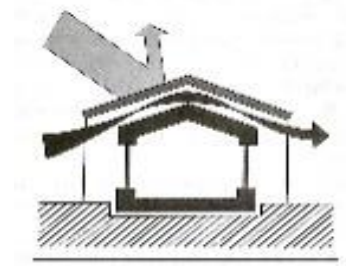

6.e

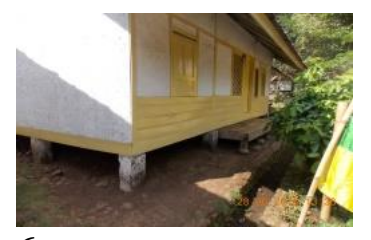

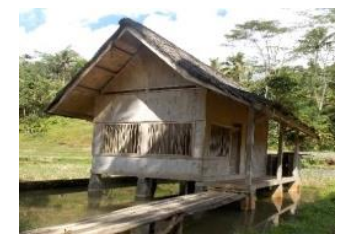

6.b

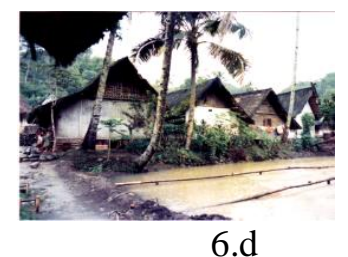

6.d

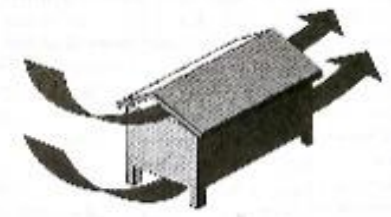

6.f
Gambar.6a,b,c,d,e,f.

Bentuk panggung rumah Sunda

Sumber : Dokumen pribadi

Keunikan dari rumah sunda berpanggung ini adalah adanya rongga diantara lantai di ruang dalam dan tanah tempt berpijak yang disebut "kolong" (ruang kosong), dimanfaatkan sebagai tempat menyimpan kayu, bambu atau benda lain untuk berkehidupan, terkait dengan iklim setempat ruang ini dimanfaatkan sebagai pendingin ruang diatasnya. Ruang tidur (enggon) adalah ruang privat maka selayaknya berada disisi belakang, Ruang Tamu (tepas) sebagai ruang public berada disisi depan rumah dilengkapi dengan ruang depan (golodog), terbuat dari bale bambu digunakan untuk penghuni menerima tamu, bercengkrama, dapur (pawon) area yang menimbulkan bau, udara panas dan kotorkarenanya dapur ditmepatkan disisi luar yang bersifat publik.

\section{Rumah Jawa}

Rumah Jawa adalah bagian dari bangunan arsitektur Jawa.Beberapa tipe bangunan arsitektur Jawa antara lain tipe Joglo, Limasan dan Kampung, masing ${ }^{2}$ tipe dihuni oleh golongan masyarakat tertentu mengikuti strata masyarakat,seperti misalnya tipe joglo saat itu umumnya dihuni oleh kaum bangsawan, akan tetapi penggolongan tersebut sekarang sudah tidak lagi, rumah jawa joglo yang men- jadi objek kajian di desa Bade,berbentuk persegi empat, tanpa lantai (langsung ke tanah), saat ini beberapa rumah ditutup dengan adukan semen. Dinding dari kayu nangka atau anyaman bambu ("gedhek") akan mengurangi rambatan panas akibat sinar matahari, akibatnya disiang hari kenyamanan suhu moderat, ruang yang frekwensi penggunaannya banyak adalah ruang tengah (ruang tamu) karenanya ditempatkan ditengah rumah, ruang tidur ditempatkan disisi tepi bangunan agar pada malam hari ruang tidur terasa hangat karena simpanan suhu tinggi di siang hari diimbangi oleh aliran udara dingin malam yang masuk kedalam melalui cela ${ }^{2}$ dinding dari ruang luar. Atap dan tiang dibuat dari kayu jati, kaso dari Bambu atau kayu nangka, penutup atap dari genteng tanah liat bakar, dibawah atap tidak ditempatkan plafond agar udara panas dapat keluar melalui cela ${ }^{2}$ antara dinding dan atap keluar bangunan (lihat gambar 6e) pada siang dan malam hari. Terdapat dua bentuk atap yaitu Sinom dan "Dorogepak" kedua tipe ini sedikit membuat ventilasi silang karena udara luar tidak melalui hanya satu ruangan.

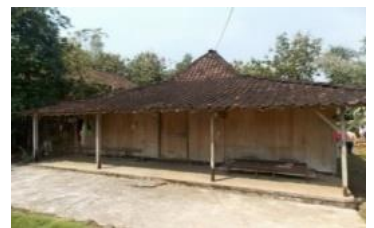

7.a

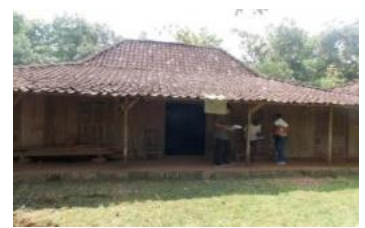

7.b
Gambar.7 a, dan 7b,

Bentuk rumah Jawa Joglo"Sinom" Sumber : Dokumen pribadi 


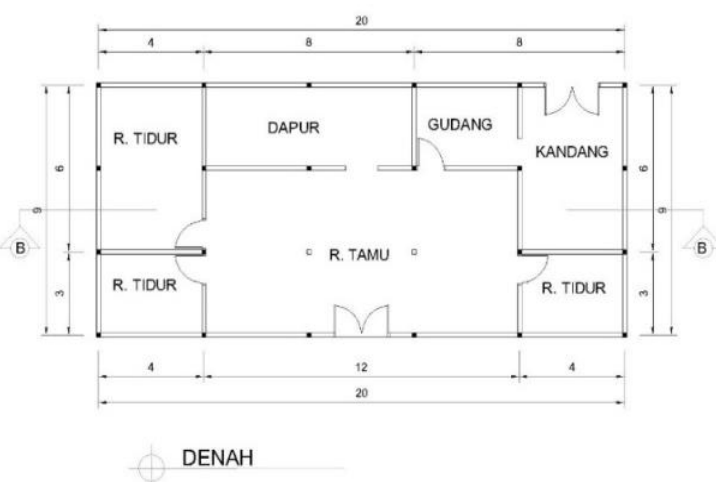

Gambar.8. Denah rumah Jawa "JogloSinom" Sumber : Dokumen pribadi

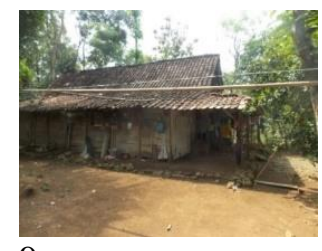
$9 . \mathrm{a}$ Gambar.9 a, dan b.

Bentuk rumah Jawa Joglo"Daragepak" Sumber : Dokumen pribadi

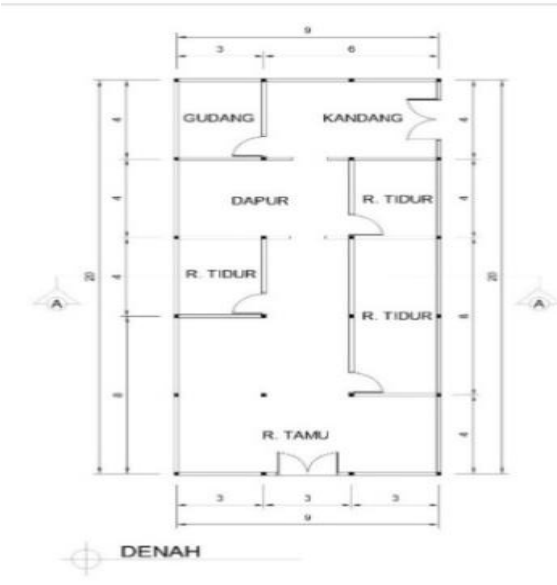

Gambar 10. Denah rumah Jawa Joglo "Daragepak"

Sumber : Dokumen pribadi

Penduduk juga melakukan ritual secara taat dan berkelanjutan ketika akan melakukan kegiatan berkaitan dengan kehidupan, seperti persiapan memulai perdagangan, persiapan pembangunan rumah, bersyukur atas nikmat yang didapat dan terimakasih kepada Tuhan YME, Kegiatan ini dilakukan secara antusias, karena mengingat pada leluhur dan alam sekitar. Akan tetapi saat ini ketaatan pada adat tidak selalu dilakukan karena dipengaruhi oleh keyakinan religi bahwa yang dilakukan adalah kemusrikan terhadap agama dan dipengaruhi oleh kemajuan teknologi dengan segala kemudahannya maka banyak penduduk desa Bade yang berurbanisasi ke kota besar membawa perubahan pengetahuan dan kemajuan teknologi, menganggap kekinian (modernism) lebih maju maka harus menerapkan wawasan baru ke kampung halaman sehingga kesetiaan terhadap adat istiadat menjadi luntur, terjadi pergeseran budaya, dibuktikan oleh banyaknya rumah jawa di Kampung Bade yang tergusur oleh bentuk rumah modern akibat pergeseran budaya.

Tabel 3. Karakter Rumah Sunda dan Jawa

\begin{tabular}{|c|c|c|c|}
\hline $\begin{array}{l}\mathbf{N} \\
\mathbf{0}\end{array}$ & Tinjauan & $\begin{array}{c}\text { Rumah } \\
\text { Sunda }\end{array}$ & $\begin{array}{c}\text { Rumah } \\
\text { Jawa }\end{array}$ \\
\hline 1. & Tipologi & $\begin{array}{l}\text { Rumah } \\
\text { Panggung }\end{array}$ & Rumah Datar \\
\hline 2. & $\begin{array}{l}\text { Bentuk } \\
\text { rumah }\end{array}$ & $\begin{array}{l}\text { Bujur } \\
\text { sangkardan } \\
\text { Persegiempat }\end{array}$ & $\begin{array}{l}\text { persegi } \\
\text { empat }\end{array}$ \\
\hline 3. & Dimensi & $\begin{array}{l}6.00 \mathrm{~m} \times 6.00 \mathrm{~m} \\
6.00 \mathrm{~m} \times 9.00 \\
\mathrm{~m} \text { atau } \\
6.00 \mathrm{~m} \times 10.00 \mathrm{~m}\end{array}$ & $\begin{array}{l}9.00 \mathrm{~m} \mathrm{x} \\
12.00 \mathrm{~m} \text { atau } \\
9.00 \mathrm{~m} \mathrm{x} \\
15.00 \mathrm{~m}\end{array}$ \\
\hline 4. & $\begin{array}{l}\text { Elemen } \\
\text { Bangunan } \\
\text { Pondasi }\end{array}$ & $\begin{array}{l}\text { Tatapakan } \\
\text { berdiri diatas } \\
\text { tanah }\end{array}$ & $\begin{array}{l}\text { Umpak } \\
\text { tertanam }\end{array}$ \\
\hline & $\begin{array}{r}\text { Bahan } \\
\text { Bentuk } \\
\text { ukuran } \\
\text { Sistim } \\
\text { kerja }\end{array}$ & $\begin{array}{l}\text { Batu kali satu } \\
\text { utuh } \\
\text { Balok vertikal } \\
20 \mathrm{~cm} x 20 \mathrm{~cm} x 6 \\
0 \mathrm{~cm} \\
\text { Tatapakan } \\
\text { bertumpu } \\
\text { ketanah } \\
\text { menyanggah } \\
\text { tihang melalui } \\
\text { gela- } \\
\text { garhorizontal/ } \\
\text { glagursarang. } \\
\text { Sistim ini } \\
\text { termasuk } \\
\text { Sistim } \\
\text { engsel(NonRig } \\
\text { id Frame) }\end{array}$ & $\begin{array}{l}\text { Susunan batu } \\
\text { bata } \\
\text { Balok } \\
\text { vertikal } \\
25 \times 25 \mathrm{~cm} \times 40 \\
\mathrm{~cm} \\
\text { Tertanam } \\
\text { ditanah } 25 \mathrm{~cm} \\
\text { disatukan } \\
\text { oleh angkur } \\
\text { ke tiang, ba } \\
\text { lok } \\
\text { glagar/hori } \\
\text { zontal } \\
\text { disatukan pd } \\
\text { tiang oleh } \\
\text { sambungan } \\
\text { ekor burung } \\
\text { dikunci oleh } \\
\text { pasak } \\
\text { bambu. } \\
\text { Sistim ini } \\
\text { termasuk } \\
\text { Sistim engsel } \\
\text { (Non Rigid } \\
\text { Frame) }\end{array}$ \\
\hline 5. & $\begin{array}{l}\text { Lantai } \\
\text { Bahan }\end{array}$ & $\begin{array}{l} \pm 60 \mathrm{~cm} \text { diatas } \\
\text { tanah }\end{array}$ & $\begin{array}{l}\text { Langsung } \\
\text { ketanah }\end{array}$ \\
\hline
\end{tabular}




\begin{tabular}{|c|c|c|c|}
\hline 6. & $\begin{array}{l}\text { Tiang/ } \\
\text { Kolom } \\
\text { Bahan } \\
\text { Bentuk } \\
\text { ukuran } \\
\\
\text { Sistim } \\
\text { kerja }\end{array}$ & $\begin{array}{l}\text { Bambu atau } \\
\text { Papan kayu } \\
\text { suren, } \\
\text { Jalinan bambu } \\
\text { disebut } \\
\text { palupuh. } \\
\text { Bambu } \\
\text { panjang } 3.00 \mathrm{~m} \\
\varnothing \text { min } 20 \mathrm{~cm} \text {, } \\
\text { papan lebar } 15 \\
\text { cm tebal } 2 \mathrm{~cm} . \\
\text { Jalinan atau } \\
\text { lembaran } \\
\text { papan } \\
\text { disanggah } \\
\text { gelagar } \\
\text { (gagalur } \\
\text { sarang) dr kayu } \\
\text { manglid } \\
\text { Tiyang } \\
\text { Kayu manglid/ } \\
\text { suren balok } \\
\text { 10x10x300cm, } \\
\text { atau } \\
\text { 5x10x250-300 } \\
\text { cm } \\
\text { Bertumpu pada } \\
\text { pondasi tanpa } \\
\text { perekat.Tiang } \\
\text { disatukan } \\
\text { dengan gelagar } \\
\text { (gagalur pada } \\
\text { arah } \\
\text { pendek/sarang } \\
\text { di arah } \\
\text { panjang). } \\
\text { Sistim ini } \\
\text { termasuk Non } \\
\text { Rigid Frame } \\
\text { (engsel) }\end{array}$ & $\begin{array}{l}\text { Soko } \\
\text { Kayu jati / } \\
\text { kayu sengon } \\
\text { balok } \\
12 \times 12 \times 350 \mathrm{c} \\
\mathrm{m}, \\
(5 \times 10 \times 300- \\
350) \\
\text { Bertumpu pd } \\
\text { pondasi } \\
\text { direkat } \\
\text { dengan } \\
\text { angkur. } \\
\text { Tiang } \\
\text { disatukan pd } \\
\text { gelagar, dgn } \\
\text { sambungan } \\
\text { ekor burung } \\
\text { dilekat kan } \\
\text { oleh pasak } \\
\text { bambu.terma } \\
\text { suk } \\
\text { NonRigidFfr } \\
\text { ame (engsel) }\end{array}$ \\
\hline & & Sumber: Do & kumen Pribadi \\
\hline $\mathrm{T}$ & $\begin{array}{r}\text { Penguku } \\
\text { ermasuk ran } \\
\text { abel 4.Aspel }\end{array}$ & $\begin{array}{l}\text { ran kategori pada } \\
\text { ah kearifan lokal, } \\
\text { HIJAU Rumah\& } \\
\text { Tradisional }\end{array}$ & $\begin{array}{l}\text { Aspek HIJAU } \\
\text { (Appendix A). } \\
\text { Kampung }\end{array}$ \\
\hline No & Aspek & tinjauan & $\begin{array}{ll}\text { Kampu } & \text { Kampu } \\
\text { gg Naga } & \text { ng Bade }\end{array}$ \\
\hline 1 & $\begin{array}{l}\text { Kategori } \\
\text { Tanah }\end{array}$ & Tepat Guna & $25 \quad 24$ \\
\hline
\end{tabular}

\begin{tabular}{|c|c|c|c|}
\hline & Kategori $\quad$ Effisiensi & 15 & 11 \\
\hline & Konservasi Energi & & \\
\hline 3 & $\begin{array}{l}\text { Kategori konservasi } \\
\text { sumber daya air }\end{array}$ & 9 & 9 \\
\hline 4 & $\begin{array}{l}\text { Kategori Daur dan } \\
\text { Sumberdaya material }\end{array}$ & 28 & 25 \\
\hline 5 & $\begin{array}{l}\text { Kategori Kesehatan \& } \\
\text { Kenyamanan ruang }\end{array}$ & 19 & 18 \\
\hline 6 & $\begin{array}{l}\text { Kategori Manajemen } \\
\text { LingkunganBangunan } \\
\text { TOTAL NILAI }\end{array}$ & 23 & 18 \\
\hline
\end{tabular}

Tabel 5.Elemen objek kajian terkait bencana Sumber: Hasil Analisa penyusun

\begin{tabular}{|c|c|c|c|c|}
\hline No & Item Kajian & Name & Material & Bentulk \\
\hline 1 & Tipology & $\begin{array}{l}\text { Panggung } \\
\text { Datar }\end{array}$ & $\begin{array}{l}\text { Kayu dan } \\
\text { atau } \\
\text { bambu }\end{array}$ & $\begin{array}{l}\text { Bujur sangkar / } \\
\text { persegi empat }\end{array}$ \\
\hline 2 & Pondasi & $\begin{array}{l}\text { Tumpuan/s } \\
\text { etapak }\end{array}$ & $\begin{array}{l}\text { Batu atau } \\
\text { Bata }\end{array}$ & $\begin{array}{l}\text { Kubus atau } \\
\text { datar }\end{array}$ \\
\hline 3 & Lantai & $\begin{array}{l}\text { Tertutup/m } \\
\text { uka tanah }\end{array}$ & $\begin{array}{l}\text { Tertutup } \\
\text { atau tidak } \\
\text { tertutup }\end{array}$ & $\begin{array}{l}\text { Plat datar } \\
\text { \&persegienpat }\end{array}$ \\
\hline 4 & Tiang & $\begin{array}{l}\text { enamatau } \\
\text { empattiang } \\
\text { utama }\end{array}$ & $\begin{array}{l}\text { Kayu atau } \\
\text { bambu }\end{array}$ & $\begin{array}{l}\text { Tiang atau } \\
\text { Kolom kokoh }\end{array}$ \\
\hline 5 & Dinding & $\begin{array}{l}\text { Dinding } \\
\text { Pemisah }\end{array}$ & $\begin{array}{l}\text { Rayu atal } \\
\text { bamboo }\end{array}$ & $\begin{array}{l}\text { Papan kayu atau } \\
\text { jalinan }\end{array}$ \\
\hline 6 & Pintu & $\begin{array}{l}\text { Pintu } \\
\text { dangan } \\
\text { daun pintu } \\
\text { atau hanya } \\
\text { lubang } \\
\text { terbuka }\end{array}$ & $\begin{array}{l}\text { Kayu atau } \\
\text { bamboo }\end{array}$ & $\begin{array}{l}\text { Papan atau } \\
\text { Jalinan }\end{array}$ \\
\hline$?$ & Jendela & $\begin{array}{l}\text { Dengan } \\
\text { daun } \\
\text { jendela } \\
\text { atau tanpa } \\
\text { daun } \\
\text { jendela }\end{array}$ & $\begin{array}{l}\text { Kayu atau } \\
\text { bambu }\end{array}$ & $\begin{array}{l}\text { Daun jendela } \\
\text { atau Kisikisi } \\
\text { (tanpa daun } \\
\text { Jendela atau } \\
\text { anyaman sasag } \\
\text { vertikal }\end{array}$ \\
\hline
\end{tabular}

Pembuktian bahwa kearifan lokal dapat dijadikan alat untuk bersikap tanggap terhadap kedaruratan bencana dilakukan dengan mengkaitkan table diatas melalui pengukuran nilai pendekatan terhadap keadaan kedaruratan

\section{Hasil Diskusi}

1. Dari penilaian diatas rumah Sunda di Kampung Naga memperlihatkan keseimbangan dan proporsi yang cukup dalam pembagian zona sesuai kebutuhan, Kampung Naga meraih nilai maximum karena sumbermatapencaharian dan kehidupan dapat ditemukan di tempat, sementara jika dibandingkan dengan Kampung Bade penghuni tetap berinteraksi dengan dunia luar untuk berkehidupan..

2. Penilaian kategori effisiensi konservasi energy di Kampung Naga didapati nilai maksimal antara lain karena adanya larangan menggunakan sumber energy kelistrikan pada penghuni rumah. 
Sementara kelistrikan di Kampung Bade tetap dilaksanakan bukti bahwa emisi di Rumah Sunda emisi di Rumah Jawa tinggi

3. Kedua rumah tradisional di kedua kampung memiliki nilai yang sama antara lain karena adanya mata air, aliran sungai dan keberadaan waduk yang mendukung kebutuhan penghuni. Kedua kampung tetap dapat memanfaatkan dan memelihara sumberdaya air

4. Kedua kampong memiliki sumberdaya untuk penerapan aturan preservasi dan daur ulang, penerapannya melalui aksiritual saat penebangan pohon, dan penerapan jadwal masa potong,tanam dan pemeliharaan hutandi awal musim penghujan.

5. Tinjauan tentang pendekatan untuk kesehatan dan kenyamanan ruang dilestarikan di kedua lokasi, pemeliharaan sumberdaya untuk menanggapi cuaca, gempa bumi,angintopan antara lain dengancara material dipilih hanya yang layak pakai dengan pengawetan, dilapisi bahan organic seperti kapur, dijemur sesuai waktu yg dibutuhkan.

6. Kampung Naga menunjukan ketaatan pada adat istiadat sebagai kearifan lokal dan Kampung Bade konsisten melakukan penerapan adat istiadat dikomunitasnya sebagai wujud pelestarian kearifan lokal.

7. Lingkungan yang dimaksud adalah alam, dipelihara dengan cara tidak merubah topographi dan kandungan didalam tanah (top soil),tidak mencampurkan zat anorganik dipersa-wahan, perkebunan atau kolam ikan.

8. Melakukan penanaman kembali hutan dan vegetasi dihalaman rumah untuk tanggap pada iklim dan musim. Antisipasi terhadap perubahan eko-logi akibat pertambahan usia alam.

9. Bangunan atau rumah bukan saja sebagai sarana untuk memenuhi kebutuhan manusia berlindung, se-bagai nilai kepuasan pada benda yang dibanggakan,sebagai bagian dari ragam budaya - adat istiadat,harus dipertahankan dan dilestarikan.

10. Manusia sebagai penghuni dan pelakudialam,berkeyakinanbahwa aturan berkehidupan harus dijaga karenaberkaitan dengan adat istiadat, tidak hanya mewarnai kebudayaan, seyogyanya menjaga, melestarikan warna budayanya terutama kearifan lokal.

11. Lingkungan, bangunan, manusia harus disatukan dan dijadikan pertimbangansecara serentak (simultaneously) dalam antisipasi dan tanggap pada bencana.

\section{PENUTUP}

Simpulan :

Bahwa penelitian ini sebagai awal kecintaan pada kearifan lokal suatu daerah untuk mengexploitasi bagian warisan budaya, sebagai harta yang tak terbayarkan, dan sebagai sumber kehidup an.Indonesia yang penuh dengan keaneka ragaman termasuk keanekaragaman bencana ternyata jika taat terhadap tuntutan alam dan kearifan lokal akan ditemukan cara untuk mengantisipasi dan menaggapi terjadinya bencana serta membatasi dampak yang terjadi.

Masalah yang harus di telusuri dan ditemukan pemecahannya adalah membuat masyarakat taat pada aturan kehidupan,adat istiadat, budaya setempat dan dapat mempertahankan diri dari pengaruh wawasan, pengetahuan, tekno logi baru (modern) yang negative tanpa meninggalkan kekhususan, keunikan, kearifan setempat.

Saran:

Bahwa penelitian lanjutan diharapkan untuk dapat memecahan permasalahan yang belum terjawab dan penelitian dilakukan dari berbagai aspek dengan sudut pandang seluas mungkin agar jawaban hipothesa yang ditemukan semakin utuh dan bulat.

\section{DAFTAR PUSTAKA}

Buku

Indartoro,IKAMPUNG NAGA 1987. A study of the relationship between beliefs, tradition and the pattern of a traditional village. Yogyakarta-Laboratory of the History and Developmentof Architecture.

Yudohusodo, Siswono. dkk 1991. Rumah Untuk Seluruh Rakyat. Jakarta: UP Bharakerta.

Maria, Siti, dkk 1995. Sistem Keyakinan pada Masyarakat Kampung Naga dalam mengelolaLingkungan Hidup (Studi Tentang Pantangan dan Larangan). Departemen Pendidikan dan Kebudayaan RI.

Lippsmeier,Georg.1997.Tropical

Building (terjemahan) Jakarta: Erlangga.

Dinas Pariwisata dan Kebudayaan provinsi Jawa Barat. Pemerintah Kabupaten Tasimalaya 
(2001) KAMPUNG NAGA Permukiman Warisan Karuhun.Tasikma laya.

Salura Purnama. 2007. Menelusuri Arsitektur Masyarakat Sunda.: Penerbit Ciptasastrasalura Bandung

Frick,Heinz and Tri Hesti M.2006.Ecological Architecture Yogyakarta: Kanisius.

Sangkertadi.2012.Kenyamanan Termis di Ruang Luar Beriklim Tropis Lembap Bandung: Alfabeta.

Anwar, Hendi.2013. Ethnic House of Sundanese. Depok: Griya Creations.

Rapp,Oliver Johannes.2015. Kota di Jawa tempo doeloe. Jakarta. Kepustakaan Populer Gramedia.

Idham,NoorCholis.2016. Arsitektur Kenyamanan Termal. Yogyakarta: Andi Publisher.

Karyono, Tri Harso. 2016.Arsitektur Tropis: Jakarta. Erlangga.

Dawson Barry and John Gillow (1994)TheTraditional Architecture of IndonesiaThames and Hudson Ltd London.

\section{Jurnal}

Susan Clare Roaf,-Natural Ventilation of Buildings in India-2001- Journal of Climate Responsive Architecture. ISBN 0-07-463218-3 Tata McGraw-Hill Publishing Company Limited. pp. 156.

Amin Sumadyo. H -Peranan Bahan dan jarak bangunan terhadap Kondisi Termal pada Rumah Tradisional Duku Pancot Tawangmangu - 2004

KOMPOSISI Journal of Archhitecture, October.ISSN 1411-6618.Architecture Programme-Faculty of Engineering-Atmajaya University Yogyakarta Indonesia pp 131

Agung Wahyudi.dan C Widi Pratiwi - Efforts Sunda Traditional Building Design Approach for Local Wisdom, Green And Save (Upaya Perancangan Bangunan Tradisional Sunda Sebagai Pendekatan Kearifan Lokal, Ramah Lingkungan Dan Hemat Energi)- 2012Journal of National Simposium RAPI XI 4 Mart ISSN 1412-9612 Engineering Faculty Muhhamadyah University Surakarta Indonesia. pp A30

Gerarda Orbita Ida Cahyandari.-Tata Ruang dan Elemen Arsitektur pada Rumah Jawa di Yogyakarta sebagai Wujud Kategori pola Aktivitas dalam Rumah Tinggal-2012 KOMPOSISI Journal of Archhitecture.October ISSN 1411-6618.Architecture ProgrammeFaculty of Engineering-Atmajaya University Jakarta Indonesia pp 103.
Tecky, Andrian, Yani dan Dita,TelaahPenghawaan Udara Alami pada Ruang Dalam Rumah Kuncen di Kampung Pulo, Online Jourrnal Institut Teknologi Nasional - Juni 2014, pp. 3.

Handajani A, Aliviana D, Fajar Kurniawati, The Influence of Micro Climate Aspect to Minimalist Landed Houses and Vernacular Stilt House -2017- Livase on line journal of Livable Space April 26 ${ }^{\text {th }}$ ISSN2548-7515 Trisakti University. Jakarta.at EJournal@trisakti.ac.idpp 45

Kontributor: Dwita Hadi Rahmi http://arsitekturdanlingkungan.wg.ugm.ac.id/2 015/11/20/pengaturan-penghawaan-danpencahayaan-pada-bangunan/ 